Arq. Bras. Med. Vet. Zootec., v.63, n.6, p.1323-1329, 2011

\title{
Chronic intestinal pseudo-obstruction in a dog: case report
}

\author{
[Pseudo-obstrução intestinal crônica em um cão: relato de caso] \\ A.L. Bicalho ${ }^{1}$, A.P.C. Silva ${ }^{1}$, T.A. Paixão $o^{2}$, R.B. Cardoso $J r^{3}$, R.L. Santos ${ }^{1 *}$ \\ ${ }^{1}$ Escola de Veterinária - Universidade Federal de Minas Gerais \\ Av. Presidente Antônio Carlos, 6627 \\ Caixa Postal 567 \\ 30161-970 - Belo Horizonte, MG \\ ${ }^{2}$ Instituto de Ciências Biológicas - Universidade Federal de Minas Gerais - Belo Horizonte, MG \\ ${ }^{3}$ Médico veterinário autônomo
}

\begin{abstract}
Intestinal pseudo-obstruction is a rare disorder that affects gastrointestinal propulsion. It may be secondary to several pathological conditions or it may develop without a known cause. A 1.2 year-old intact Pug bitch had a history of vomiting and constipation, which were followed by diarrhea and distended abdomen. Hypomotility and dilation of the small intestine, which was filled with gas, were observed during laparotomy. Histologically, full thickness biopsy specimens demonstrated a severe loss and degeneration of leiomyocytes in the inner and outer muscular layers of the intestinal wall, whereas there was a marked hypertrophy and hyperplasia of smooth muscle cells in the lamina propria, and extremely thickened muscularis mucosae arranged in bundles oriented in different directions with marked hypertrophy and hyperplasia of leiomyocytes. Distribution of leiomyocytes was further characterized by immunohistochemistry. These findings support the diagnosis of intestinal pseudo-obstruction in a Pug, associated with degeneration and loss of leiomyocytes in the muscular layer.
\end{abstract}

Keywords: dog, pseudo-obstruction, intestine

\section{RESUMO}

A pseudo-obstrução intestinal é um distúrbio raro que afeta a propulsão gastrointestinal. Pode ser secundária a diversas condições patológicas ou pode ser idiopática. Uma cadela Pug de um ano e dois meses de idade apresentou histórico de vômitos e constipação, que foram seguidos por diarreia $e$ distensão abdominal. Hipomotilidade e dilatação do intestino delgado, que estava cheio de gás, foram observados durante a laparotomia. Ao exame histológico, observou-se grande perda e degeneração de leiomiócitos das camadas musculares interiores e exteriores da parede intestinal, com acentuada hipertrofia e hiperplasia das células do músculo liso da lâmina própria e espessamento acentuado da muscularis mucosae com feixes orientados em direções diferentes e acentuada hipertrofia e hiperplasia dos leiomiócitos. A distribuição de leiomiócitos foi caracterizada por imunoistoquímica. Estes resultados suportam o diagnóstico de pseudo-obstrução intestinal em um Pug, associado à degeneração e perda de leiomiócitos da camada muscular.

Palavras chave: cão, pseudo-obstrução, intestino

Recebido em 27 de março de 2011

Aceito em 9 de setembro de 2011

*Autor para correspondência (corresponding author)

E-mail: rsantos@vet.ufmg.br 


\section{INTRODUCTION}

Intestinal pseudo-obstruction is a rare disorder that affects the intestinal motility. It is characterized by impaired gastrointestinal propulsion, which is associated with clinical signs of bowel obstruction in the absence of luminal occlusion of the intestine (Coulie and Camilleri, 1999).

This syndrome may develop as a secondary event to several pathological conditions, including hypokalaemia, myocardial infarction, spinal or pelvic trauma, abdominal surgery, and retroperitoneal hemorrhage (De Giorgio et al., 2001) or it may be idiopathic. Furthermore, it may have an acute or a chronic clinical course. Chronic intestinal idiopathic pseudo-obstruction (CIIP) is the most common presentation, and it affects either the neural or the muscular elements of the intestinal wall (Schuffler, 1981). CIIP is an important cause of chronic functional intestinal failure (De Giorgio et al., 2009).

In some cases, CIIP has also been recognized as a familial trait, with an autosomal dominant recessive mode of inheritance (De Giorgio and Camilleri, 2004). Nevertheless, most cases of CIIP appear to be sporadic, and not related to familial clusters (De Giorgio et al., 2009).

In humans, symptoms related with this disorder are nausea, vomiting, abdominal distention, constipation, dysphagia, abdominal pain, diarrhea and steatorrhoea, possibly caused by bacteria overgrowth, abnormal motility or a hypersecretory state (Di Lorenzo, 1999).

Here the occurrence of chronic intestinal pseudoobstruction in a Pug, which was associated with loss of smooth muscle tissue in the intestinal wall was reported.

\section{CASE REPORT}

A 1.2 year-old intact Pug bitch presented episodes of variable gastro intestinal clinical signs, including vomiting and constipation, which were followed by diarrhea and distended abdomen, leading to severe weight loss. Initially, the episodes occurred approximately once a month, and then they became more frequent (twice a month, once a week, and every two days). Blood chemistry indicated no changes other than increased amylase levels when the first clinical signs were observed.

Food allergy was considered in the differential diagnosis. Therefore, a food trial was performed using a hypoallergenic homemade diet, and then a commercial hypoallergenic diet. She was also treated with metoclopramide, domperidone, dimethicona and ranitidine. Sulfasalazine was also prescribed when she developed clinical signs compatible with colitis.

Ultrasound examination indicated gastric and intestinal distention, containing gas and fluid. The diameter of the small intestine was approximately $4 \mathrm{~cm}$, and its motility was subjectively considered decreased. There were some feces within the colon, and also small amounts of free abdominal fluid that were not sampled. Endoscopy was performed and demonstrated gross changes compatible with gastritis, and a normal duodenal mucosa.

In order to have an accurate diagnosis, the animal was submitted to an exploratory laparotomy, and full thickness biopsy of small and large intestine were performed. Fragments of small and large intestine were fixed by immersion in $10 \%$ buffered formalin for 24 hours. Samples were then dehydrated, and processed for paraffin embedding. Five $\mu \mathrm{m}$ sections were cut and stained with hematoxylineosin, Masson's trichrome, Picrosirius and Immunohistochemistry (primary antibody 1A4) for smooth muscle actin.

Upon laparotomy, the small intestine was markedly dilated with gas. The intestinal wall appeared grossly thin with some hyperemic areas. No peristalsis was observed throughout the small intestine (supplementary data). The large intestine appeared grossly normal, with normal tonus and motility, and it contained normal appearing feces. No other abnormalities were observed.

Several small intestine fragments were examined. These samples consistently had both muscular layers segmentally thinner with multiple foci of degeneration and loss of leiomyocytes, resulting in complete loss of the muscular layer in some segments (Fig. 1A). Degenerative changes were characterized primarily by vacuolation and hyalinization of 
leiomyocytes (Fig. 1A). In contrast, extremely thickened muscularis mucosae (several hundred micrometers-thick) was observed, with severe hypertrophy and hyperplasia of leiomyocytes, arranged in bundles oriented in different directions (Fig. 1B). There was marked hypertrophy and hyperplasia of smooth muscle cells of the lamina propria, particularly in the villi (Fig. 2), and Masson's trichrome staining demonstrated minimal to moderate amount of collagen fibers between leiomyocytes (Fig. 3).
Picrosirius staining under polarized light demonstrated that collagen fibers within the muscular layer and muscularis mucosae were composed primarily of type III collagen (Fig. 4). Immunostaining of smooth muscle actin demonstrated an extensive increase in the population of leiomyocytes in the lamina propria (Fig. 5A) and muscularis mucosae (Fig. 5B), whereas there was a marked segmental loss of leiomyocytes in the muscular layer (Fig. 5C).

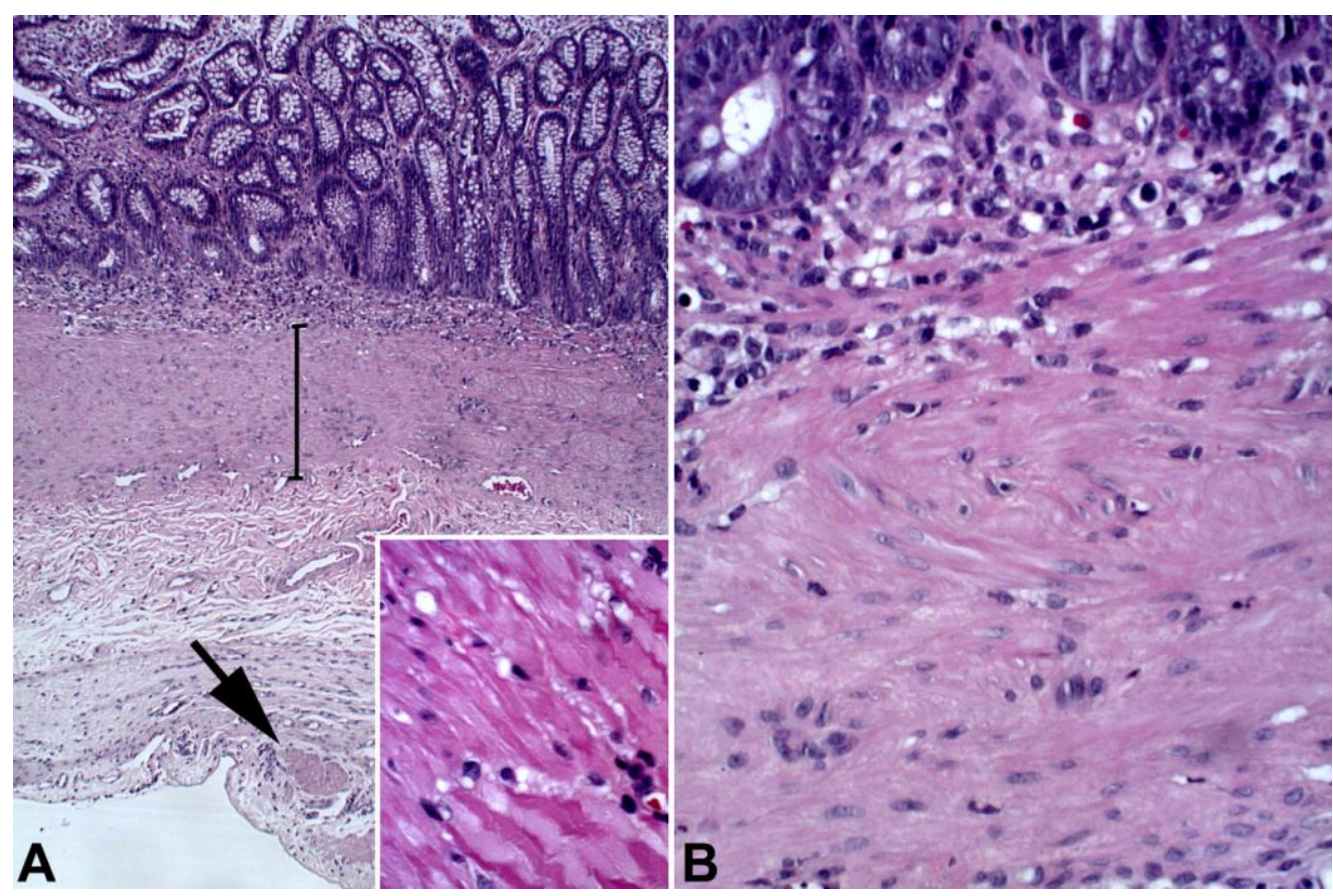

Figure 1. Dog. Small intestine. (A) Extremely thickened muscularis mucosae (several hundred micrometers-thick) (bar) and complete loss of muscular layer in some segments (arrow). HE. 10x. Detail: hyalinization, vacuolation and loss of leiomyocytes in the muscular layer. (B) Thickened muscularis mucosae with severe hypertrophy and hyperplasia of leiomyocytes, arranged in bundles oriented in different directions HE. 40x.

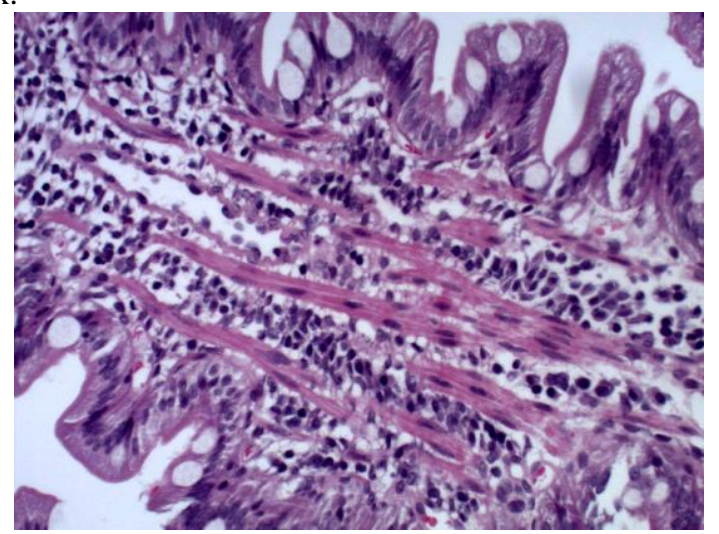

Figure 2. Dog. Small intestine - Marked hypertrophy and hyperplasia of smooth muscle cells of the lamina propria, particularly in the villi. HE. 10x. 


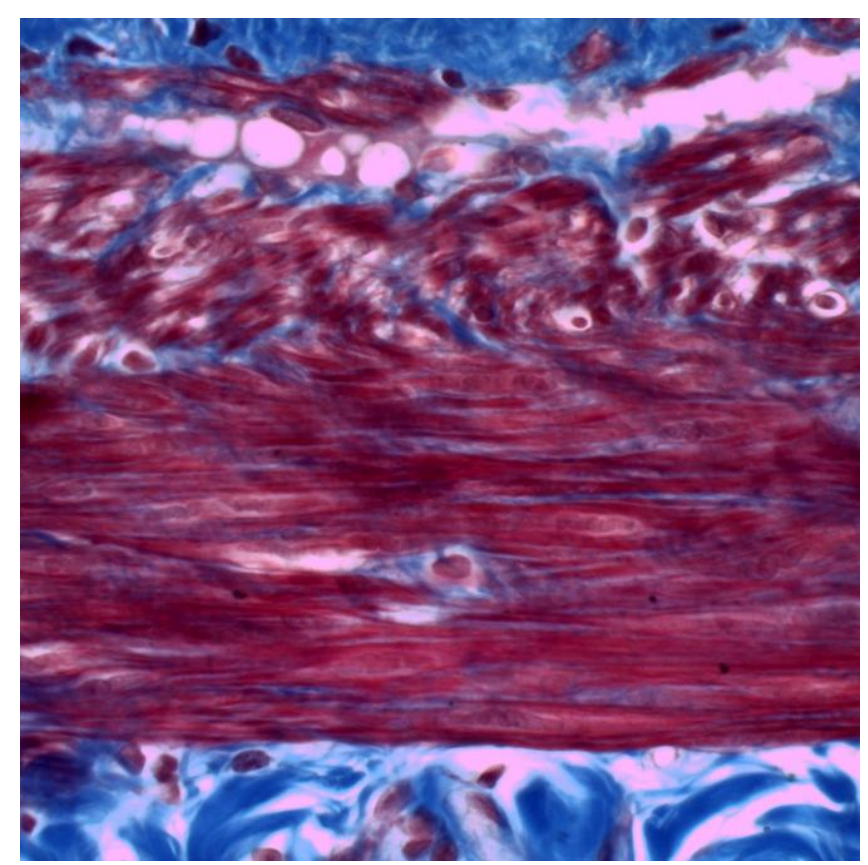

Figure 3. Dog. Small intestine - Minimal to moderate amount of collagen fibers (blue) between leiomyocytes (red). Masson's trichrome. 40x.

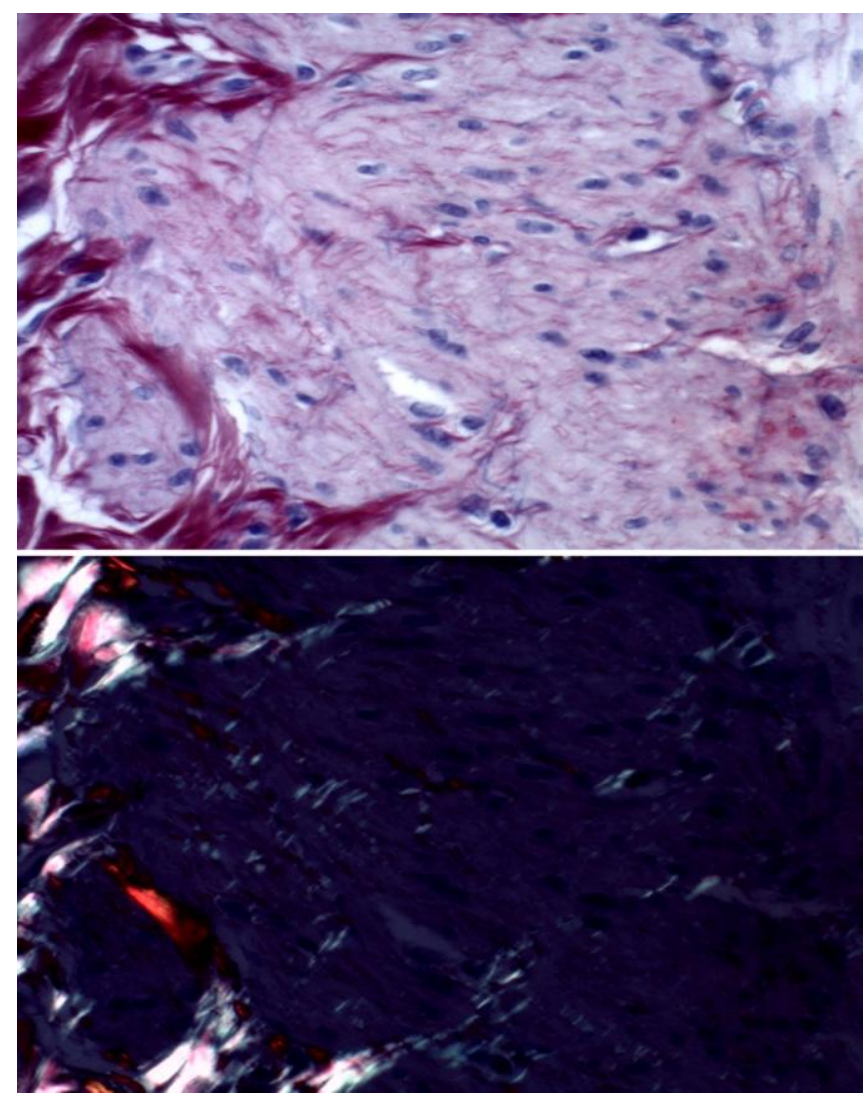

Figure 4. Dog. Small intestine. Collagen fibers within the muscular layer and muscularis mucosae were composed primarily of type III collagen as demonstrated by picrosirius staining under polarized light (green refringency at the bottom panel). Picrosirius staining under polarized light. 40x. 


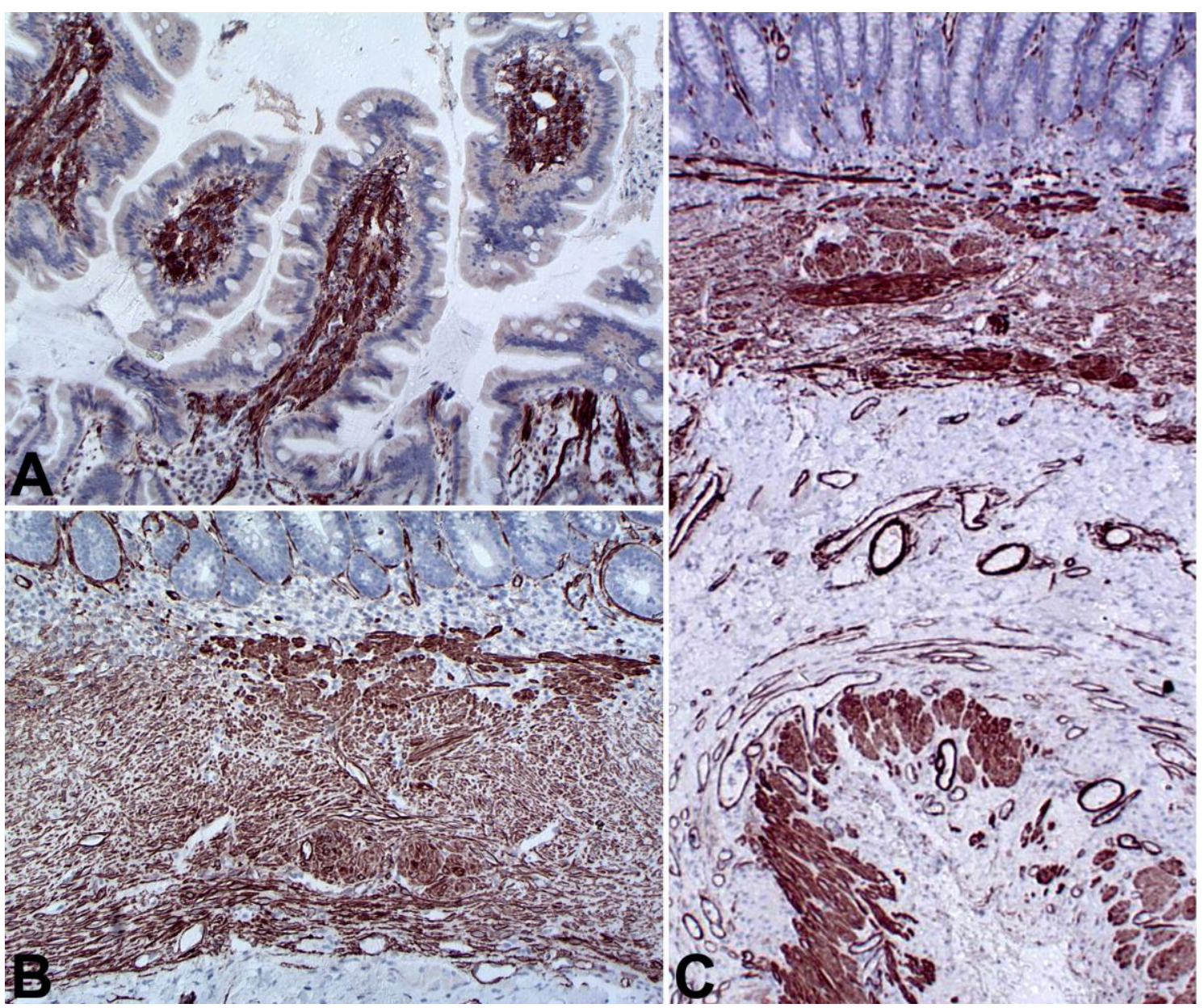

Figure 5. Dog. Small intestine. (A) Immunostaining of smooth muscle acting demonstrating an extensive increase in the population of leiomyocytes in the lamina propria, IHC. 10x, and (B) muscularis mucosae, IHC. 10x. (C) Immunostaining of smooth muscle actin demonstrating a marked segmental loss of leiomyocytes in the muscular layer. IHC. 10x.

\section{DISCUSSION}

Clinical history and histopathological findings in this case are consistent with chronic intestinal pseudo-obstruction as a result of a leiomiopathy associated with degeneration and loss of leiomyocytes in the muscular layer, and a compensatory hypertrophy and hyperplasia of leiomyocytes in the lamina propria, as well as hypertrophy and hyperplasia of the muscularis mucosae.

Chronic intestinal pseudo-obstruction is uncommon in veterinary medicine (Johnson et al., 2007), but it is a well described condition in humans. The syndrome has been reported in dogs (Arrick and Kleine, 1978; Dvir et al., 2001;
Eastwood et al., 2005), in two cats (Harvey et al., 2005), and in one horse (Burns et al., 1990).

In previous reported cases of CIIP in dogs, vomiting was the only consistent finding, although abnormal feces were frequently observed as well as weight loss, poor appetite, and abdominal distention. Similar clinical signs were observed in the present case, including vomiting, constipation, diarrhea, distended abdomen, and weight loss.

The diagnosis of CIIP is largely based on clinical signs, supported by X Rays and ultrasound, which may demonstrate dilated bowel with gas and fluid in the absence of mechanical obstructions. 
It has been reported that in patients with CIIP a barium contrast may take from 10 days (Johnson et al., 2007) to 3 weeks (Couraud et al., 2006) to move from the stomach to the small intestine. Endoscopy could be used for exclusion of mechanical obstruction, however superficial endoscopic biopsies would not help diagnosis due to the deeper level of the lesion (Schuffler, 1981). Auxiliary diagnostic tests are required in patients suspected of CIIP in order to identify underlying causes of decreased intestinal motility including pancreatitis, hypocalcemia, hipokalemia, Addison's, hypothyroidism, diabetes or diseases of enteric nervous system.

Full thickness intestinal biopsies might be the only diagnostic procedure that allows an appropriate diagnosis in a case such as the one reported here. Dilated and hypomotile small intestine loops were the main findings by some authors as observed in this case, whereas cecal impaction was found by Eastwood et al. (2005), which was not observed in the present case.

Importantly, the most frequently reported microscopic lesions of CIIP in dogs are fibrosis and infiltration of the smooth muscle fibers of the tunica muscularis by mononuclear cells (Dvir et al., 2001; Eastwood et al., 2005). Fibrosis in the present case was ruled out based on trichrome staining, which did not demonstrate any excessive accumulation of collagen. Furthermore, picrosirius staining under polarized light demonstrated that most of the collagen associated with the muscular tissue was composed of type III collagen (Junqueira et al., 1979). These lesions are in sharp contrast to the changes observed in the present case, in which there was degeneration and loss of the muscular layer, with a compensatory hypertrophy and hyperplasia of the muscularis mucosae. This compensatory change has been previously reported in one case (Arrick and Kleine, 1978). Immunohistochemistry was a valuable tool for the assessment of the distribution of leiomyocytes, increasing the accuracy of evaluation of the degenerative or progressive changes in the intestinal muscular tissue.

There is no curative treatment for CIIP. Antibiotics may result in short-term relief in some cases, probably due to the control of secondary bacterial overgrowth. The use of liquid meals with appropriate fiber contents may help patients with gastroparesis (Di Lorenzo, 1999).

\section{ACKNOWLEDGEMENTS}

We thank Adriana Amantino Martins for technical support. RLS has a scholarship from CNPq (Conselho Nacional de Desenvolvimento Científico e Tecnológico, Brazil), and APCS has a scholarship from FAPEMA (Fundação de Amparo a Pesquisa e ao Desenvolvimento Científico e Tecnológico do Maranhão).

\section{REFERENCES}

ARRICK, R.H.; KLEINE, L.J. Intestinal pseudoobstructionin a dog. J. Am. Vet. Med. Assoc., v.172, p.1201-1205, 1978.

BURNS, G.A.; KARCHER, L.F.; CUMMINGS, J.F. Equinemyenteric ganglionitis: a case of chronic intestinal pseudo-obstruction. Cornell Vet., v.80, p.53-63, 1990.

COULIE, B.; CAMILLERI, M. Intestinal pseudo-obstruction. Annu. Rev. Med., v.50, p.3755, 1999.

COURAUD, L.; JERMYN, K.; YAM, P. S. et al. Intestinal pseudo-obstruction, lymphocytic leiomyositis and atrophy of the muscularis externa in a dog. Vet. Rec., v.159, p.86-87, 2006.

DE GIORGIO, R.; BARBARA, G.; STANGHELLINI, V. et al. Review article: the pharmacological treatment of acute colonic pseudo-obstruction. Aliment. Pharmacol. Ther., v.15, p.1717-1727, 2001.

DE GIORGIO, R.; CAMILLERI, M. Human enteric neuropathies: morphology and molecular pathology. Neurogastroenterol. Motil., v.5, p.515-531, 2004.

DE GIORGIO, R.; SARNELLI, G.; CORINALDESI, R. et al. Advances in our understanding of the pathology of chronic intestinal pseudo-obstruction. Gut, v.53, p.15491552, 2009.

DI LORENZO, C. Pseudo-obstruction: current approaches. Gastroenterology, v.116, p.980-987, 1999.

DVIR, E.; LEISEWITZ, A.L.; VAN DER LUGT, J.J. Chronic idiopathic intestinal pseudoobstruction in an English bulldog. J. Small Anim. Pract., v.42, p.243-247, 2001. 
EASTWOOD, J.M.; McINNES, E.F.; WHITE, R.N. et al. Caecal impaction and chronic intestinal pseudo-obstruction in a dog. J. Vet. Series A-Physiol. Pathol. Clinic. Med., v.52, p.43-44, 2005.

HARVEY, A.M.; HALL, E.J.; DAY, M.J. et al. Chronic intestinal pseudo-obstruction in a cat caused by visceral myopathy. J. Vet. Intern. Med., v.19, p.111-114, 2005.

JOHNSON，C.S.; FALES-WILLIAMS， A.J.; REIMER, S.B. et al. Fibrosing gastrointestinal leiomyositis as a cause of chronic intestinal pseudo- obstruction in an 8-month-old dog. Vet. Pathol., v.44, p.106-109, 2007.
JUNQUEIRA, L.C.; BIGNOLAS, G.; BRETANI, R.R. Picrosirius staining plus polarization microscopy, a specific method for collagen detection in tissue sections. Histochem. J., v.11, p.447-455, 1979.

SCHUFFLER, M.D. Chronic intestinal pseudoobstruction syndromes. Med. Clin. N. Am., v.65, p.1331-1358, 1981. 